\title{
Improving the Salinity Tolerance in Wheat Plants Using Salicylic and Ascorbic Acids
}

\author{
El-Sayed M. Desoky ${ }^{1}$ \& Abdel-Rahman M. Merwad ${ }^{2}$ \\ ${ }^{1}$ Agriculture Botany Department, Faculty of Agriculture, Zagazig University, Egypt \\ ${ }^{2}$ Soil Science Department, Faculty of Agriculture, Zagazig University, Egypt \\ Correspondence: Abdel-Rahman M. Merwad, Soil Science Department, Faculty of Agriculture, Zagazig \\ University, Zagazig 44511, Egypt. Tel: 20-121-214-4240. E-mail: abdo.soil@yahoo.com
}

Received: May 27, 2015 Accepted: July 23, 2015 Online Published: September 15, 2015

doi:10.5539/jas.v7n10p203

URL: http://dx.doi.org/10.5539/jas.v7n10p203

\begin{abstract}
A pot experiment was conducted during 2013/2014 and 2014/2015 successive growing winter seasons under greenhouse conditions at the Experimental Station, Fac. of Agric., Zagazig Univ., Sharkia Governorate, Egypt to evaluate the response of wheat plants (Triticum aestivum L.) cv. Sakha 93 to different levels of foliar spray of some antioxidant tested substances as ascorbic and salicylic acids at a rate of 0.1 and $0.2 \%$, with respect to vegetative criteria, some physiological properties i.e. phenol components, proline concentration, yield components, NPK-uptake as well as anatomical structure of flag leaf blade grown under salt stress conditions, $3.21 \mathrm{dSm}^{-1}, 6.32 \mathrm{dSm}^{-1}$ and $10.65 \mathrm{dSm}^{-1}$ of soil salt. Data indicated that, all studied vegetative criteria of wheat plants, decreased under salt stress condition. Spraying antioxidant substances seemed to partially overcome the harmful effects of salt stress on vegetative criteria. Significant increase in the concentrations of phenols component and proline concentration in response to salt stress treatments. Also, application of tested antioxidant significantly reduced phenols component and increase proline concentration in leaves under water stress condition. Dry matter of straw and grain and yield quality, straw and grains N, P and K-uptake were decreased with increasing the soil salinity level. This trend was found true under all foliar sprays with salicylic and ascorbic acids at different rates. The highest values of straw and grain yield, biological yield, weight of 1000 grain, protein content and yield efficiency, straw and grains N, P and K-uptake of wheat plants occurred with ascorbic acid $0.2 \%$ "AA2" treatment followed by ascorbic acid $0.1 \%$ "AA1", salicylic acid $0.2 \%$ "SA2", salicylic acid $0.1 \%$ "SA1" and untreated plants that descending order in the two seasons.
\end{abstract}

Keywords: wheat plants, salinity, ascorbic acid, nutrient uptake, salicylic acid, anatomical structure

\section{Introduction}

Wheat is the most important cereal crop. It is stable diet for the world population and contributes more calories and protein to the world diet more than only other cereal crop. It is grown on roughly 200 million hectares with an average production of 600 million tons (Rajarm \& Braun, 2006). Wheat is a major food crop in most of the countries of the world which suffer saline soils, and therefore increasing salinity tolerance in bread wheat is necessary (Sadat Noori \& McNeilly, 2000).

Salinity is considered a major factor in limiting plant growth and crop productivity, and salinisation of irrigated and surrounding areas in the arid tropics and sub-tropics has not been diminished. On the contrary, it continues to increase in arid and semi-arid regions (Rus et al., 2000). It is estimated that about a third of the world's cultivated land is affected by salinity (Perez-Alfocea et al., 1996). The relationships between salinity and mineral nutrition of horticultural crops are extremely complex and a complete understanding of the indicate interactions involved would require the input from a multidisciplinary team of scientists (Grattan \& Grieve, 1999). Salinity can be minimised with reclamation, water and drainage, but the cost of engineering and management is very high.

Ascorbic acid (AA) is regarded as one of the most effective growth regulators against a biotic stresses (Conklin, 2001). AA not only acts as an antioxidant but the cellular levels of AA are correlated with the activation of complex biological defence mechanisms (Conklin \& Barth, 2004). It has also been used to counteract the adverse effects of salt stress in many crop plants (Beltagi, 2008). It has proposed functions in whole plant metabolism (Debolt et al., 2007). Furthermore, experimental studies on different plants have shown that 
exogenous application of AA may reduce saltinduced adverse effects and results in a significant increment of growth and yield (Salama, 2009).

Salicylic acid (SA) acts as an endogenous signal molecule responsible for inducing abiotic stress tolerance in plants (Gunes et al., 2007). Salicylic acid is an endogenous growth regulator of phenolic nature, which participates in the regulation of physiological processes in plant (Shakirova et al., 2003).

Therefore, the present study was undertaken to investigate the effect of foliar spray with antioxidants, i.e. ascorbic and salicylic acids at a rate of $0.1 \%$ and $0.2 \%$ on vegetative criteria, some physiological, yield, nutrient uptake and anatomical structure of leaf blade of wheat plants grown under different levels of salinity stress.

\section{Materials and Methods}

A pot experiment was carried out during the two successive growing winter seasons of 2013/2014 and 2014/2015, under greenhouse conditions at the Experimental Station, Fac. Agric., Zagazig Univ., El-Sharkia Governorate, Egypt, to study the effect of foliar spray of antioxidants as Ascorbic acid (AA) and Salicylic acid (SA) on plant vegetative criteria, some physiological and NPK-uptake, anatomical structure of wheat plants leaf blade as well as yield component of wheat plants (Triticum aestivum L., cv. Sakha 93) grown under different levels of salinity stress.

Wheat grains were obtained from Wheat Research Section, Crops Research Institute, Agriculture Research Centre, Giza. Grains were sown on the $29^{\text {th }}$ November in both investigated seasons.

Three saline soils having almost the same near texture were collected from El-Noubaria, near Alexandria, Egypt .Closed bottom plastic pots of internal dimensions $25 \times 20 \mathrm{~cm}$ were filled with $10 \mathrm{~kg}$ of each saline soil (3.21, 6.32, $\left.10.65 \mathrm{dSm}^{-1}\right)$. The physical and chemical properties of the investigated soil were determined according to Piper (1950); Black et al. (1968) and Jackson (1973) are shown in Table 1.

Table 1. Some physical and chemical properties of the investigated soils in both seasons

\begin{tabular}{|c|c|c|c|c|c|c|c|c|c|c|c|c|c|c|c|c|c|c|c|c|}
\hline \multicolumn{5}{|c|}{ Soil particles distribution } & \multicolumn{8}{|c|}{ Chemical analyses } & \multirow{3}{*}{ 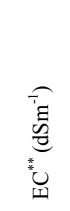 } & \multirow{3}{*}{$\stackrel{*}{\text { 蓲 }}$} & \multirow{3}{*}{ 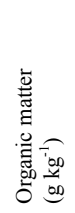 } & \multirow{3}{*}{ 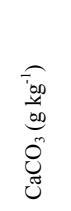 } & \multirow{3}{*}{ 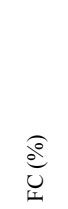 } & \multirow{2}{*}{\multicolumn{3}{|c|}{$\begin{array}{l}\text { Available nutrient } \\
\text { (mg kg-1 soil ) }\end{array}$}} \\
\hline \multirow{2}{*}{$\begin{array}{l}\text { Soil } \\
\text { salinity }\end{array}$} & \multirow{2}{*}{$\begin{array}{l}\text { Sand } \\
y(\%)\end{array}$} & \multirow{2}{*}{$\begin{array}{l}\text { Silt } \\
(\%)\end{array}$} & \multirow{2}{*}{$\begin{array}{l}\text { Clay } \\
(\%)\end{array}$} & \multirow{2}{*}{$\begin{array}{l}\text { Textural } \\
\text { class }\end{array}$} & \multicolumn{4}{|c|}{$\begin{array}{l}\text { Cations** } \\
\left(\text { mmolc } L^{-1}\right)\end{array}$} & \multicolumn{4}{|c|}{$\begin{array}{l}\text { Anions }{ }^{* *} \\
\left(\mathrm{mmol}_{\mathrm{c}} \mathrm{L}^{-1}\right)\end{array}$} & & & & & & & & \\
\hline & & & & & $\mathrm{Ca}^{++}$ & $\mathrm{Mg}^{++}$ & $\mathrm{Na}^{+}$ & $\mathrm{K}^{+}$ & $\mathrm{CO}_{3}^{-}$ & $\mathrm{HCO}_{3}^{-}$ & $\mathrm{Cl}^{-}$ & $\mathrm{SO}_{4}^{--}$ & & & & & & $\mathrm{N}$ & $\mathrm{P}$ & K \\
\hline S1 & 42.52 & 32.42 & 25.06 & Loam & 9.89 & 10.57 & 7.23 & 4.31 & - & 8.41 & 12.72 & 10.87 & 3.21 & 7.95 & 7.87 & 60.26 & 14.67 & 62.30 & 10.62 & 102.6 \\
\hline S2 & 44.56 & 30.56 & 24.88 & Loam & 19.23 & 18.46 & 16.56 & 8.75 & - & 22.12 & 30.26 & 10.62 & 6.32 & 7.91 & 8.36 & 65.80 & 15.32 & 54.35 & 7.18 & 92.70 \\
\hline S3 & 45.62 & 29.85 & 24.53 & Loam & 41.54 & 27.5 & 19.35 & 17.61 & - & 39.26 & 30.47 & 36.27 & 10.65 & 8.09 & 9.81 & 70.50 & 15.76 & 49.50 & 4.98 & 85.32 \\
\hline
\end{tabular}

Note. *: Soil paste; **: Soil paste extract; FC: Field capacity.

The treatments were of three levels of soil salinity as $3.21 \mathrm{dSm}^{-1}(\mathrm{~S} 1), 6.32 \mathrm{dSm}^{-1}(\mathrm{~S} 2)$ and $10.65 \mathrm{dSm}^{-1}$ (S3) and different levels of antioxidants, i.e. Ascorbic acid (AA) and Salicylic acid (SA) at $0.1 \%$ and $0.2 \%$ were applied as a foliar spray treatments. Fifteen grains/pot were sown at equal distances and depth. After two weeks from sowing, seedlings were thinned to eight seedlings/pot.

Mineral nitrogen was added as ammonium sulphate $\left(205 \mathrm{~g} \mathrm{~kg}^{-1}\right)$ at the rate of $100 \mathrm{mg} \mathrm{N} \mathrm{kg}^{-1}$ soil, respectively in three equal splits. The first was before the $1^{\text {st }}$ irrigation while the second and third splits were added after 40 and 70 days, respectively from the first splits. The recommended doses of phosphorus and potassium were added; for all experimental treatments as ordinary super phosphate $\left(65 \mathrm{~g} \mathrm{P} \mathrm{kg}^{-1}\right)$ at the rate of $15 \mathrm{mg} \mathrm{P} \mathrm{kg}^{-1}$ soil before sowing. Potassium was added as potassium sulphate $\left(410 \mathrm{~g} \mathrm{~K} \mathrm{~kg}^{-1}\right)$ at the rate of $40 \mathrm{mg} \mathrm{K} \mathrm{kg}^{-1}$ soil before sowing.

Foliar applications of Ascorbic acid (AA) and Salicylic acid (SA) were carried out three times using hand atomizer and wetting agent after 25, 45 and 65 days from sowing under S1, S2 and S3 salinity stress conditions. Control plants were sprayed with distilled water and the volume of the spraying solution of the tested antioxidant was maintained just to cover completely the plant foliage till drip.

\subsection{Plant Vegetative Characters}

A random sample of three plants were taken from each treatment at 75 days old (booting stage) during each growing season to record plant vegetative characters and physiological properties. Plant height $(\mathrm{cm})$, blade leaf 
area $\left(\mathrm{cm}^{2}\right)$ of flag leaf on main stem, and dry weight/plant $(\mathrm{g})$ of shoot systems were determined. Plant samples were dried using an electric oven with drift fan at $70{ }^{\circ} \mathrm{C}$ for $48 \mathrm{~h}$. till a constant weight was reached.

\subsection{Physiological Properties}

A - Phenolic compounds: Free, bound and total phenols were determined using the colorimetric method as described by F. D. Snell and C. T. Snell (1954). Preparation of Folin - Denis reagent as described by Gutfinger (1981).

$B$ - Bound Phenols: The difference between total and free phenol concentrations gives the concentration of bound phenols.

$C$ - Proline concentration: Proline concentration was determined according to the method given by Bates et al. (1973).

\subsection{Yield and Its Components}

At harvest, plant samples were separated into straw and grains, dried at $70{ }^{\circ} \mathrm{C}$ for 72 hours, weighed, digested with concentration $\mathrm{H}_{2} \mathrm{SO}_{4} / \mathrm{HCLO}_{4}$ and analyzed for total nitrogen, phosphorus and potassium (Chapman \& Pratt, 1961). Total nitrogen in plant was determined using the microkjeldahl method according to Chapman and Pratt (1961). Total potassium in plant was determined by flame photometer according to Chapman and Pratt (1961). Total phosphorus in plant was determined colourmetrically using ascorbic acid method (Watanabe \& Olsen, 1965). Protein percent "yield quality" in grains was calculated by multi plying N\% $\times 5.70$ (Bishni \& Hughes, 1979).

\subsection{Anatomical Responses}

Anatomical blade sections were made by Nassar and El-Sahhar (1998) method.

\subsection{Statistical Analysis}

The treatments were of three levels of soil salinity and five levels of antioxidants (Ascorbic and Salicylic acids). The experiment included 15 treatments in 6 replicates, so the experiment contained 90 pots and the design was a factorial randomized complete block. Data were subjected to statistical analysis according to Snedecor and Cochran (1990). Mean values were compared at $\mathrm{P}<0.05$ using the least significant different test (LSD).

\section{Results and Discussion}

\subsection{Plant Vegetative Parameters}

Data presented in (Table 2) show the main effect of foliar application with antioxidants (AA and SA) on vegetative parameters i.e., plant height, leaf area and shoot dry weight of wheat plants grown under different levels of soli salinity.

Data revealed that all vegetative parameters were significantly decreased by increasing soil salinity levels in both seasons, the low salinity treatment $\left(3.21 \mathrm{dSm}^{-1}\right)$ reduced these parameters to a lesser degree than the moderate salinity $\left(6.32 \mathrm{dSm}^{-1}\right)$ and high salinity $\left(10.65 \mathrm{dSm}^{-1}\right)$.

These results were agreed with Hussain and Ismail (1994) who suggested that growth rate reduced response to Nacl salinity. While Murtaza et al. (2006) stated that wheat growth parameters were reduced with irrigation by saline and/or sodic water.

Salinity of soil and irrigation water reduces vegetative and reproductive growth and yield in most crops. However, the mechanisms involved in growth inhibition due to the excess salinity are complex and poorly understood. The mail inhibitory effect of salinity on plant growth has been attributed to osmotic inhibition of the absorption of available water, specific ion effect causing excessive accumulation of $\mathrm{Na}^{+}$or $\mathrm{Cl}^{-}$or inadequate uptake of an essential nutrient, hormonal imbalance and accumulation of toxic intermediate products as free radical oxygen (Roy et al., 1995; Bray, 1993).

Data also indicated that plant vegetative parameters significantly increased by spraying plants with AA \& SA compared to untreated plant in both seasons. These results are in agree with Hussien et al. (2007) who reported that spraying maize plant with SA at rate $200 \mathrm{ppm}$ improved growth parameters i.e., plant height, leaf area and dry weight of stem. Also Abd El-Aziz et al. (2006) indicated that spray plants with AA at rates 200 or $400 \mathrm{ppm}$ had significant increase in all growth parameters i.e., stem length, leaf area and dry weight of all plant organs.

Concerning the interaction effect between foliar application with AA \& SA and different levels of soil salinity plant height, leaf area and shoot dry weight data indicated that spraying wheat plants with AA \& SA increased plant growth Parameters grown under soil salinity levels and the highest values of plant growth Parameters were 
recorded with AA at rate $0.2 \%$ followed by AA at rate $0.1 \%$, SA at rate $0.2 \%$ finally SA at rate $0.1 \%$ compared with untreated one (control).

These results are in agreement with Batool Ejaz et al. (2012) who found that application of AA increased shoot length and leaf area of Saccharum spp under both salt stressed and non stressed condition. While Smirnoff (1996), stated that ascorbate has been implicate in the regulation in cell division, he said also that cell wall ascorbate and cell wall localized ascorbate oxidase has been implicate in control of growth, high ascorbate oxidase is associated with rapidly expanding cell. While Gunes et al. (2007) found that it has been proposed that salicylic acid acts as endogenous signal molecule responsible for inducing a biotic stress tolerance in plants. They emphasized that exogenous application of SA increased plant growth significantly both in saline and non saline conditions.

Table 2. Main effects of foliar spray with antioxidants on plant height, leaf area and dry weight of shoot of wheat plants grown under salinity stress in 2013/2014-2014/2015 seasons

\begin{tabular}{|c|c|c|c|c|}
\hline \multirow{2}{*}{ Salinity (A) } & \multirow{2}{*}{ Treatment of foliar (B) } & \multicolumn{3}{|c|}{ Season 2013-2014 } \\
\hline & & Plant height (cm ) & Leaf area $\left(\mathrm{cm}^{2}\right)$ & Dry weight of shoot $\left(\mathrm{g} \mathrm{plant}^{-1}\right)$ \\
\hline \multirow{5}{*}{ S1 } & Without & 69.50 & 13.07 & 0.97 \\
\hline & SA1 & 87.33 & 14.52 & 1.05 \\
\hline & SA2 & 87.67 & 17.64 & 1.11 \\
\hline & AA1 & 88.00 & 19.28 & 1.18 \\
\hline & AA2 & 89.00 & 20.76 & 1.35 \\
\hline \multirow[t]{3}{*}{ Mean } & & 84.30 & 17.06 & 1.14 \\
\hline & Without & 59.00 & 8.37 & 0.69 \\
\hline & SA1 & 62.67 & 9.42 & 0.73 \\
\hline \multirow[t]{3}{*}{ S2 } & SA2 & 64.33 & 9.91 & 0.85 \\
\hline & AA1 & 65.00 & 12.12 & 0.88 \\
\hline & AA2 & 68.33 & 12.47 & 0.90 \\
\hline \multirow[t]{3}{*}{ Mean } & & 63.68 & 10.45 & 0.81 \\
\hline & Without & 31.55 & 3.87 & 0.29 \\
\hline & SA1 & 46.67 & 5.17 & 0.51 \\
\hline \multirow[t]{3}{*}{ S3 } & SA2 & 48.00 & 6.47 & 0.54 \\
\hline & AA1 & 50.00 & 7.55 & 0.56 \\
\hline & AA2 & 53.67 & 8.61 & 0.57 \\
\hline \multicolumn{2}{|l|}{ Mean } & 45.98 & 6.34 & 0.49 \\
\hline \multicolumn{5}{|c|}{ Mean of treatment (foliar spray) } \\
\hline \multicolumn{2}{|l|}{ Without } & 53.35 & 8.44 & 0.65 \\
\hline \multicolumn{2}{|l|}{ SA1 } & 65.56 & 9.70 & 0.76 \\
\hline \multicolumn{2}{|l|}{ SA2 } & 66.89 & 12.08 & 0.84 \\
\hline \multicolumn{2}{|l|}{ AA1 } & 67.67 & 12.98 & 0.87 \\
\hline \multicolumn{2}{|l|}{ AA2 } & 70.33 & 13.95 & 0.94 \\
\hline \multirow{3}{*}{ LSD $0.05 \%$} & $\mathbf{A}$ & 3.194 & 1.307 & 0.081 \\
\hline & B & 4.123 & 1.687 & 0.105 \\
\hline & $\mathbf{A B}$ & NS & NS & NS \\
\hline \multicolumn{5}{|c|}{ Season 2014-2015 } \\
\hline \multirow{5}{*}{ S1 } & Without & 73.67 & 14.84 & 1.00 \\
\hline & SA1 & 88.33 & 15.93 & 1.09 \\
\hline & SA2 & 90.13 & 18.36 & 1.15 \\
\hline & AA1 & 90.60 & 19.42 & 1.22 \\
\hline & AA2 & 91.33 & 20.88 & 1.40 \\
\hline \multicolumn{2}{|l|}{ Mean } & 86.81 & 17.88 & 1.17 \\
\hline
\end{tabular}




\begin{tabular}{lllll}
\hline & Without & 61.00 & 9.60 & 0.73 \\
S2 & SA1 & 65.50 & 10.36 & 0.77 \\
& SA2 & 67.00 & 10.74 & 0.90 \\
Mean & AA2 & 69.67 & 13.22 & 0.91 \\
& & 71.33 & 13.39 & 0.96 \\
& Without & 66.90 & 11.46 & 0.85 \\
S3 & SA1 & 33.21 & 4.52 & 0.38 \\
& SA2 & 48.33 & 5.77 & 0.55 \\
& AA1 & 51.67 & 6.87 & 0.58 \\
Mean & AA2 & 54.33 & 8.51 & 0.62 \\
Mean of treatment (foliar spray) & 57.00 & 9.02 & 0.61 \\
Without & & 48.90 & 6.94 & 0.54 \\
SA1 & & & & \\
SA2 & & 55.96 & 9.65 & 0.70 \\
AA1 & & 67.39 & 10.69 & 0.80 \\
AA2 & & 70.49 & 12.82 & 0.88 \\
& & 71.53 & 13.72 & 0.92 \\
LSD 0.05\% & B & 73.22 & 14.43 & 0.99 \\
& AB & 3.860 & 1.411 & 0.078 \\
\hline SA1 & 4.984 & 1.821 & 0.101 \\
\end{tabular}

Note. SA1 $=0.1 \%$ Salicylic acid; SA2 $=0.2 \%$ Salicylic acid; AA1 $=0.1 \%$ Ascorbic acid; AA2 $=0.2 \%$ Ascorbic acid; $\mathrm{S} 1=3 \mathrm{dSm}^{-1} ; \mathrm{S} 2=6 \mathrm{dSm}^{-1} ; \mathrm{S} 3=9 \mathrm{dSm}^{-1} ; \mathrm{NS}$ : Not significant at $\mathrm{t} 0.05$.

\subsection{Phenolic Compounds}

Data presented in (Table 3) show the main effect of foliar application with antioxidants (AA and SA) on phenolic compounds i.e., total phenols, free phenols and bound phenols in wheat plant leaves grown under different levels of salinity stress in 2013/2014-2014/2015 seasons.

The obtained results recorded the highest value of phenolic compounds under salinity stress levels S3 (10.65 $\left.\mathrm{dSm}^{-1}\right)$. While, the lowest value of phenolic compounds under salinity stress levels were recorded under $\mathrm{S}_{1}(3.21$ $\mathrm{dSm}^{-1}$ ). The above mentioned effect of salinity stress on phenolic compounds in plant leaves may be substantiated by the findings published by Zahra et al. (2012) who showed that salinity stress increased phenolics compound in leaf tissue. Phenolics change optical properties of leaves might have possibility to protect photosynthetic apparatus during drought stress. Phenol accumulation could be a cellular adaptive mechanism for scavenging oxygen free radicals during stress (Mohamed \& Aly, 2008). Spraying plants with AA\& SA affects the phenolic compounds and showed significant decrease in phenolic compounds of wheat leaves during two seasons.

Blokhina et al. (2002) stated that phenolic compounds are diverse secondary metabolites (flavonoids, tannins, hydroxycinnamate esters and lignin) abundant in plant tissues reviewed by Grace and Logan (2000). Polyphenols possess ideal structural chemistry for free radical scavenging activity.

As for the effect of the interaction between spraying plants with antioxidant treatments and drought stress levels for all phenolic compounds it has insignificant, effect indicating that each factor act independently.

\subsection{Proline Concentration}

From the data given in (Table 3) it can be concluded that proline was accumulated in leaves of wheat plants grown under salinity stress, so that proline concentration increased linearly with increasing salinity levels in both seasons. Following this Ackerson (1984) argued that, cellular osmotic adjustment occurs in response to stress via an active or passive accumulation of salts.

Ozdemir et al. (2004) reported that accumulation of proline has been considered as a carbon and nitrogen source for rapid recovery from stress and growth, stabilizer for membranes and some macro molecules and also a free radical scavenger. 
Concerning the effect of foliar application of AA \& SA on concentration of proline in wheat leaves, indicated further increase after application of AA \& SA.

Noctor and Foyer (1998) found that Ascorbate is the reductant used for the hydroxylation of proline residues during extension biosynthesis. Ascorbic acid is a major metabolic in chloroplast of higher plants and represents about $10 \%$ of the soluble carbohydrate pool in leaves (Liso et al., 1985) and is implicated in root elongation and cell wall expansion. Because phenoxyl radicals react much more readily with ascorbate than with each other, low concentrations of ascorbate can completely inhibit these oxidation reactions (Takahama \& Oniki, 1994).

Shakirova et al. (2003) found that SA-treated wheat seedlings providing the development of antistress reactions, for example, maintenance of proline accumulation.

Regarding the interaction effect between foliar application with antioxidants (AA, SA) and different levels of salinity stress on the relative content of proline in leaves of wheat plant, proline concentration was increased by foliar spray of AA \& SA. The higher proline content was recorded in plant maintained at high level S3 (10.65 $\mathrm{dSm}^{-1}$ ) after foliar spray with AA at $0.2 \%$ followed by salinized plant at the same level sprayed with AA at $0.1 \%$ followed by SA at $0.2 \%$ finally SA at $0.1 \%$. Similar results have been reported on maize by Hussein et al. (2007) who suggested that exogenous application of SA increased proline content under salinity stress conditions.

\subsection{Yield Parameters and Yield Quality}

Data presented in (Table 4) show the effect of foliar sprays with salicylic and ascorbic acids at different values on straw and grain yield, biological yield, weight of 1000 grain, protein content and yield efficiency of wheat plants grown under saline soils. All the values of foliar sprays with salicylic and ascorbic acids significantly increased yield parameters and yield quality as compared to untreated plants (without foliar spray) under all the soil salinity level in the two seasons.

Data show that, dry matter of straw, grain and yield quality were decreased with increasing the soil salinity level. This trend was found true under all foliar sprays with salicylic and ascorbic acids at different rates. As mentioned above the untreated plants (without foliar spray) at maturity stage died off due to extremely high salinity (10.65 $\left.\mathrm{dSm}^{-1}\right)$ in the two seasons. The highest values of yield parameters and yield quality occurred with AA2 treatment followed by AA1, SA2, SA1 respectively and untreated plants in descending order in the two seasons. values of yield parameters and yield quality of AA2 treatment were superior over the other treatment of both two successive seasons These results are in agreement with those obtained by Merwad and Abdel-Fattah (2015) who reported that spraying salicylic and ascorbic acids gave the highest fresh and dry weight of sorghum plants grown under saline calcareous soil conditions. From statistical analysis, results showed that the foliar spray with ascorbic acid at different rates under the saline level gave a significant increase in dry weight of straw and grain, protein content and yield efficiency compared to foliar spray with salicylic acid in the two investigated seasons. This result confirmed by El-Tayed (2005).

Table 3. Main effects of foliar spray with antioxidants on phenolic compounds and proline concentration of wheat plants grown under salinity stress in 2013/2014-2014/2015 seasons

\begin{tabular}{|c|c|c|c|c|c|}
\hline \multirow[b]{2}{*}{ Salinity (A) } & \multirow[b]{2}{*}{ Treatment of foliar (B) } & \multicolumn{4}{|c|}{ Season 2013-2014 } \\
\hline & & $\begin{array}{l}\text { Total phenols } \\
\text { (mg/gm F. wt.) }\end{array}$ & $\begin{array}{l}\text { Free phenols } \\
\text { (mg/gm F. wt.) }\end{array}$ & $\begin{array}{l}\text { Bound phenols } \\
\text { (mg/gm F. wt.) }\end{array}$ & $\begin{array}{l}\text { Proline concentration } \\
\text { ( } \mu \text { moles proline/gm F. wt.) } \\
\text { in leaves }\end{array}$ \\
\hline \multirow{5}{*}{ S1 } & Without & 1.618 & 0.569 & 1.049 & 8.79 \\
\hline & SA1 & 1.597 & 0.558 & 1.039 & 9.30 \\
\hline & SA2 & 1.516 & 0.517 & 0.999 & 10.56 \\
\hline & AA1 & 1.505 & 0.516 & 0.989 & 11.10 \\
\hline & AA2 & 1.464 & 0.495 & 0.969 & 11.65 \\
\hline \multirow[t]{3}{*}{ Mean } & & 1.540 & 0.531 & 1.009 & 10.28 \\
\hline & Without & 1.719 & 0.618 & 1.101 & 11.48 \\
\hline & SA1 & 1.698 & 0.616 & 1.082 & 11.84 \\
\hline \multirow[t]{3}{*}{ S2 } & SA2 & 1.647 & 0.584 & 1.063 & 14.01 \\
\hline & AA1 & 1.626 & 0.575 & 1.051 & 14.66 \\
\hline & AA2 & 1.565 & 0.533 & 1.032 & 15.15 \\
\hline
\end{tabular}




\begin{tabular}{|c|c|c|c|c|c|}
\hline \multirow[t]{3}{*}{ Mean } & & 1.651 & 0.585 & 1.065 & 13.42 \\
\hline & Without & 2.678 & 0.989 & 1.689 & 15.11 \\
\hline & SA1 & 1.989 & 0.828 & 1.161 & 15.80 \\
\hline \multirow[t]{3}{*}{ S3 } & SA2 & 1.797 & 0.667 & 1.130 & 19.63 \\
\hline & AA1 & 1.726 & 0.616 & 1.110 & 21.44 \\
\hline & $\mathbf{A A 2}$ & 1.685 & 0.595 & 1.090 & 22.17 \\
\hline \multicolumn{2}{|l|}{ Mean } & 1.975 & 0.793 & 1.236 & 18.83 \\
\hline \multicolumn{6}{|c|}{ Mean of treatment (foliar spray) } \\
\hline \multicolumn{2}{|l|}{ Without } & 2.01 & 0.73 & 1.28 & 11.79 \\
\hline \multicolumn{2}{|l|}{ SA1 } & 1.76 & 0.67 & 1.09 & 12.31 \\
\hline \multicolumn{2}{|l|}{ SA2 } & 1.65 & 0.59 & 1.06 & 14.95 \\
\hline \multicolumn{2}{|l|}{ AA1 } & 1.62 & 0.57 & 1.05 & 15.73 \\
\hline \multicolumn{2}{|l|}{$\mathbf{A A 2}$} & 1.57 & 0.54 & 1.03 & 16.32 \\
\hline & $\mathbf{A}$ & 0.248 & 0.043 & 0.240 & 1.037 \\
\hline \multirow[t]{2}{*}{ LSD $0.05 \%$} & B & 0.320 & 0.055 & 0.309 & 1.339 \\
\hline & $\mathbf{A B}$ & NS & 0.095 & NS & NS \\
\hline \multicolumn{6}{|c|}{ Season 2014-2015 } \\
\hline & Without & 1.759 & 0.653 & 1.106 & 9.14 \\
\hline & SA1 & 1.728 & 0.619 & 1.109 & 9.75 \\
\hline \multirow[t]{3}{*}{ S1 } & SA2 & 1.657 & 0.598 & 1.059 & 10.74 \\
\hline & AA1 & 1.616 & 0.586 & 1.030 & 11.23 \\
\hline & AA2 & 1.575 & 0.561 & 1.014 & 11.83 \\
\hline \multirow[t]{3}{*}{ Mean } & & 1.667 & 0.603 & 1.063 & 10.53 \\
\hline & Without & 1.968 & 0.794 & 1.174 & 11.66 \\
\hline & SA1 & 1.917 & 0.761 & 1.156 & 12.02 \\
\hline \multirow[t]{3}{*}{$\mathbf{S 2}$} & SA2 & 1.816 & 0.694 & 1.122 & 13.83 \\
\hline & AA1 & 1.775 & 0.661 & 1.114 & 14.74 \\
\hline & $\mathbf{A A 2}$ & 1.724 & 0.636 & 1.088 & 15.46 \\
\hline \multirow[t]{3}{*}{ Mean } & & 1.840 & 0.709 & 1.130 & 13.54 \\
\hline & Without & 2.898 & 1.125 & 1.773 & 16.03 \\
\hline & SA1 & 2.121 & 0.894 & 1.227 & 16.73 \\
\hline \multirow[t]{3}{*}{$\mathbf{S 3}$} & SA2 & 2.033 & 0.852 & 1.181 & 20.19 \\
\hline & AA1 & 1.998 & 0.828 & 1.170 & 21.82 \\
\hline & AA2 & 1.916 & 0.761 & 1.155 & 22.59 \\
\hline \multicolumn{2}{|l|}{ Mean } & 2.193 & 0.892 & 1.301 & 19.47 \\
\hline \multicolumn{6}{|c|}{ Mean of treatment (foliar spray) } \\
\hline \multicolumn{2}{|l|}{ Without } & 2.21 & 0.86 & 1.35 & 12.28 \\
\hline \multicolumn{2}{|l|}{ SA1 } & 1.92 & 0.76 & 1.16 & 12.83 \\
\hline \multicolumn{2}{|l|}{ SA2 } & 1.82 & 0.70 & 1.12 & 15.22 \\
\hline \multicolumn{2}{|l|}{ AA1 } & 1.80 & 0.69 & 1.10 & 15.93 \\
\hline \multicolumn{2}{|l|}{$\mathbf{A A 2}$} & 1.74 & 0.65 & 1.09 & 16.63 \\
\hline \multirow{3}{*}{ LSD $0.05 \%$} & $\mathbf{A}$ & 0.208 & 0.040 & NS & 0.696 \\
\hline & B & 0.268 & 0.051 & NS & 0.899 \\
\hline & $\mathbf{A B}$ & NS & 0.089 & NS & NS \\
\hline
\end{tabular}

Note. SA $1=0.1 \%$ Salicylic acid; SA2 $=0.2 \%$ Salicylic acid; AA1 $=0.1 \%$ Ascorbic acid; AA2 $=0.2 \%$ Ascorbic acid; $\mathrm{S} 1=3 \mathrm{dSm}^{-1} ; \mathrm{S} 2=6 \mathrm{dSm}^{-1} ; \mathrm{S} 3=9 \mathrm{dSm}^{-1} ; \mathrm{NS}$ : Not significant at $\mathrm{t} 0.05$. 
Table 4. Main effects of foliar spray with antioxidants on yield parameters and yield quality of wheat plants grown under salinity stress in 2013/2014-2014/2015 seasons

\begin{tabular}{|c|c|c|c|c|c|c|c|}
\hline \multirow[b]{2}{*}{ Salinity (A) } & \multirow[b]{2}{*}{ Treatment of foliar (B) } & \multicolumn{6}{|c|}{ Season 2013-2014 } \\
\hline & & $\begin{array}{l}\text { Straw yield } \\
\left(\text { g plant }^{-1}\right)\end{array}$ & $\begin{array}{l}\text { Grain yield } \\
\left(\mathrm{g} \text { plant }^{-1}\right)\end{array}$ & $\begin{array}{l}\text { Biological Yield } \\
\left(\text { g plant }^{-1}\right)\end{array}$ & $\begin{array}{l}\text { Weight of } 1000 \\
\text { grains (g) }\end{array}$ & $\begin{array}{l}\text { Protein } \\
\left(\mathrm{g} \mathrm{kg}^{-1}\right)\end{array}$ & $\begin{array}{l}\text { Efficiency yield } \\
(\%)\end{array}$ \\
\hline \multirow{5}{*}{ S1 } & Without & 1.26 & 0.66 & 1.92 & 42.90 & 137.6 & 34.21 \\
\hline & SA1 & 1.29 & 0.68 & 1.97 & 45.85 & 143.6 & 34.52 \\
\hline & SA2 & 1.32 & 0.70 & 2.02 & 48.30 & 149.5 & 34.60 \\
\hline & AA1 & 1.35 & 0.72 & 2.08 & 50.57 & 153.9 & 34.83 \\
\hline & AA2 & 1.40 & 0.76 & 2.15 & 55.35 & 158.1 & 35.14 \\
\hline \multirow[t]{3}{*}{ Mean } & & 1.32 & 0.70 & 2.03 & 48.59 & 148.5 & 34.66 \\
\hline & Without & 0.96 & 0.46 & 1.42 & 37.26 & 91.80 & 32.55 \\
\hline & SA1 & 1.12 & 0.53 & 1.65 & 38.10 & 96.90 & 32.26 \\
\hline \multirow[t]{3}{*}{ S2 } & SA2 & 1.17 & 0.58 & 1.75 & 39.37 & 113.1 & 33.08 \\
\hline & AA1 & 1.15 & 0.61 & 1.76 & 40.17 & 124.3 & 34.53 \\
\hline & AA2 & 1.25 & 0.64 & 1.90 & 41.23 & 135.7 & 33.86 \\
\hline \multirow[t]{3}{*}{ Mean } & & 1.13 & 0.57 & 1.70 & 39.23 & 112.3 & 33.25 \\
\hline & Without & 0.00 & 0.00 & 0.00 & 0.00 & 00.0 & 0.00 \\
\hline & SA1 & 0.64 & 0.37 & 1.02 & 27.67 & 68.8 & 36.72 \\
\hline \multirow[t]{3}{*}{ S3 } & SA2 & 0.78 & 0.41 & 1.20 & 28.37 & 74.7 & 34.54 \\
\hline & AA1 & 0.86 & 0.43 & 1.30 & 29.90 & 81.1 & 33.42 \\
\hline & AA2 & 0.92 & 0.45 & 1.37 & 32.00 & 87.2 & 33.25 \\
\hline \multicolumn{2}{|l|}{ Mean } & 0.64 & 0.34 & 0.98 & 23.59 & 62.4 & 27.59 \\
\hline \multicolumn{8}{|c|}{ Mean of treatment (foliar spray) } \\
\hline \multicolumn{2}{|l|}{ Without } & 0.739 & 0.372 & 1.11 & 26.72 & 76.4 & 22.25 \\
\hline \multicolumn{2}{|l|}{ SA1 } & 1.018 & 0.529 & 1.55 & 37.21 & 103.1 & 34.50 \\
\hline \multicolumn{2}{|l|}{ SA2 } & 1.093 & 0.564 & 1.66 & 38.68 & 112.4 & 34.07 \\
\hline \multicolumn{2}{|l|}{ AA1 } & 1.122 & 0.588 & 1.71 & 40.21 & 119.8 & 34.26 \\
\hline \multirow[t]{2}{*}{ AA2 } & & 1.190 & 0.619 & 1.81 & 42.86 & 127.0 & 34.08 \\
\hline & $\mathbf{A}$ & 0.0072 & 0.0063 & 0.009 & 0.361 & 1.754 & 0.392 \\
\hline \multirow[t]{2}{*}{ LSD $0.05 \%$} & B & 0.009 & 0.008 & 0.0122 & 0.467 & 2.423 & 0.459 \\
\hline & $\mathbf{A B}$ & 0.0162 & 0.0142 & 0.0211 & 0.808 & 4.015 & 0.845 \\
\hline \multicolumn{8}{|c|}{ Season 2014-2015 } \\
\hline & Without & 1.12 & 0.57 & 1.69 & 41.23 & 127.3 & 33.79 \\
\hline & SA1 & 1.16 & 0.60 & 1.77 & 45.18 & 140.6 & 34.15 \\
\hline \multirow[t]{3}{*}{ S1 } & SA2 & 1.21 & 0.64 & 1.85 & 47.49 & 151.1 & 34.59 \\
\hline & AA1 & 1.26 & 0.67 & 1.93 & 46.53 & 159.6 & 34.77 \\
\hline & AA2 & 1.29 & 0.70 & 2.00 & 54.35 & 163.6 & 35.23 \\
\hline \multirow[t]{3}{*}{ Mean } & & 1.21 & 0.64 & 1.85 & 46.96 & 148.4 & 34.51 \\
\hline & Without & 0.78 & 0.46 & 1.29 & 34.71 & 87.2 & 37.87 \\
\hline & SA1 & 0.92 & 0.49 & 1.41 & 35.40 & 92.7 & 34.60 \\
\hline \multirow[t]{3}{*}{ S2 } & SA2 & 0.97 & 0.51 & 1.49 & 36.23 & 99.9 & 34.53 \\
\hline & AA1 & 0.95 & 0.53 & 1.48 & 37.73 & 106.2 & 35.96 \\
\hline & AA2 & 1.07 & 0.55 & 1.62 & 40.13 & 109.6 & 33.95 \\
\hline \multirow[t]{3}{*}{ Mean } & & 0.93 & 0.51 & 1.44 & 36.84 & 99.1 & 35.38 \\
\hline & Without & 0.00 & 0.00 & 0.00 & 0.00 & 0.00 & 0.00 \\
\hline & SA1 & 0.58 & 0.31 & 0.90 & 28.30 & 71.3 & 34.93 \\
\hline \multirow[t]{3}{*}{ S3 } & SA2 & 0.65 & 0.37 & 1.02 & 29.63 & 78.3 & 36.48 \\
\hline & AA1 & 0.71 & 0.43 & 1.14 & 31.90 & 81.5 & 37.70 \\
\hline & AA2 & 0.76 & 0.45 & 1.22 & 33.27 & 85.3 & 37.81 \\
\hline
\end{tabular}




\begin{tabular}{|c|c|c|c|c|c|c|c|}
\hline \multicolumn{2}{|l|}{ Mean } & 0.54 & 0.32 & 0.86 & 24.62 & 63.3 & 29.38 \\
\hline \multicolumn{8}{|c|}{ Mean of treatment (foliar spray) } \\
\hline \multicolumn{2}{|l|}{ Without } & 0.63 & 0.34 & 0.97 & 25.31 & 71.50 & 23.89 \\
\hline \multicolumn{2}{|l|}{ SA1 } & 0.89 & 0.47 & 1.36 & 36.29 & 101.5 & 34.56 \\
\hline \multicolumn{2}{|l|}{ SA2 } & 0.94 & 0.51 & 1.45 & 37.79 & 109.8 & 35.20 \\
\hline \multicolumn{2}{|l|}{ AA1 } & 0.97 & 0.54 & 1.52 & 38.72 & 115.8 & 36.14 \\
\hline \multicolumn{2}{|l|}{$\mathbf{A A 2}$} & 1.04 & 0.57 & 1.61 & 42.58 & 119.5 & 35.66 \\
\hline \multirow{3}{*}{ LSD $0.05 \%$} & $\mathbf{A}$ & 0.010 & 0.008 & 0.015 & 0.317 & 1.885 & 0.421 \\
\hline & B & 0.012 & 0.010 & 0.019 & 0.409 & 2.433 & 0.543 \\
\hline & $\mathbf{A B}$ & 0.022 & 0.018 & 0.033 & 0.708 & 4.215 & 0.941 \\
\hline
\end{tabular}

Note. SA $1=0.1 \%$ Salicylic acid; SA2 $=0.2 \%$ Salicylic acid; AA $1=0.1 \%$ Ascorbic acid; AA2 $=0.2 \%$ Ascorbic acid; $\mathrm{S} 1=3 \mathrm{dSm}^{-1} ; \mathrm{S} 2=6 \mathrm{dSm}^{-1} ; \mathrm{S} 3=9 \mathrm{dSm}^{-1}$.

\subsection{Nutrient Uptake}

Data presented in (Table 5) show that the effect of foliar sprays with salicylic and ascorbic acids at different rates on N,P and K uptake of wheat plants grown under saline soils, All the rates of foliar sprays with salicylic and ascorbic acids significantly increased straw and grain $\mathrm{N}, \mathrm{P}$ and $\mathrm{K}$ uptake as compared to untreated plants (without foliar spray) grown under all the soil salinity level in the two seasons.

Table 5. Main effects of foliar spray with antioxidants on straw and grain NPK-uptake of wheat plants grown under salinity stress in 2013/2014-2014/2015 seasons

\begin{tabular}{|c|c|c|c|c|c|c|c|}
\hline \multirow{3}{*}{ Salinity (A) } & \multirow{3}{*}{ Treatment of foliar (B) } & \multicolumn{6}{|c|}{ Season 2013-2014 } \\
\hline & & \multicolumn{3}{|c|}{ Straw (mg plant $\left.{ }^{-1}\right)$} & \multicolumn{3}{|c|}{$\operatorname{Grain}\left(\right.$ mg plant $\left.^{-1}\right)$} \\
\hline & & N-uptake & P-uptake & K-uptake & N-uptake & P-uptake & K-uptake \\
\hline \multirow{5}{*}{ S1 } & Without & 19.52 & 3.69 & 32.42 & 18.16 & 2.31 & 18.16 \\
\hline & SA1 & 20.94 & 4.08 & 36.64 & 20.67 & 2.56 & 20.67 \\
\hline & SA2 & 23.03 & 4.54 & 40.59 & 22.87 & 2.82 & 22.87 \\
\hline & AA1 & 25.94 & 4.96 & 46.46 & 26.28 & 3.14 & 26.28 \\
\hline & AA2 & 32.60 & 6.38 & 51.69 & 29.51 & 3.83 & 29.51 \\
\hline \multirow[t]{3}{*}{ Mean } & & 24.41 & 4.73 & 41.56 & 23.50 & 2.93 & 23.50 \\
\hline & Without & 12.67 & 1.41 & 17.18 & 9.22 & 0.90 & 9.22 \\
\hline & SA1 & 15.46 & 2.17 & 20.64 & 10.90 & 1.40 & 10.90 \\
\hline \multirow[t]{3}{*}{ S2 } & SA2 & 17.52 & 2.62 & 22.92 & 12.49 & 1.70 & 12.49 \\
\hline & AA1 & 18.51 & 2.88 & 24.91 & 14.37 & 1.98 & 14.37 \\
\hline & AA2 & 21.99 & 3.44 & 32.20 & 17.80 & 2.25 & 17.80 \\
\hline \multirow[t]{3}{*}{ Mean } & & 17.23 & 2.50 & 23.58 & 12.96 & 1.65 & 12.96 \\
\hline & Without & 0.00 & 0.00 & 0.00 & 0.00 & 0.00 & 0.00 \\
\hline & SA1 & 6.41 & 0.47 & 8.73 & 5.81 & 0.54 & 5.81 \\
\hline \multirow[t]{3}{*}{ S3 } & SA2 & 9.35 & 0.71 & 11.83 & 7.07 & 0.66 & 7.07 \\
\hline & AA1 & 10.91 & 0.98 & 14.53 & 8.16 & 0.79 & 8.16 \\
\hline & AA2 & 11.92 & 1.31 & 16.22 & 8.92 & 0.97 & 8.92 \\
\hline Mean & & 7.72 & 0.69 & 10.26 & 5.99 & 0.59 & 5.99 \\
\hline \multicolumn{8}{|c|}{ Mean of treatment (foliar spray) } \\
\hline Without & & 10.73 & 1.70 & 16.54 & 9.13 & 1.069 & 9.128 \\
\hline SA1 & & 14.27 & 2.24 & 22.00 & 12.46 & 1.500 & 12.462 \\
\hline
\end{tabular}




\begin{tabular}{|c|c|c|c|c|c|c|c|}
\hline \multicolumn{2}{|l|}{ SA2 } & 16.63 & 2.62 & 25.11 & 14.14 & 1.729 & 14.142 \\
\hline \multicolumn{2}{|l|}{ AA1 } & 18.45 & 2.94 & 28.63 & 16.27 & 1.970 & 16.269 \\
\hline \multirow[t]{2}{*}{ AA2 } & & 22.17 & 3.71 & 33.39 & 18.74 & 2.353 & 18.743 \\
\hline & $\mathbf{A}$ & 0.602 & 0.128 & 0.755 & 0.610 & 0.039 & 0.402 \\
\hline \multirow[t]{2}{*}{ LSD $0.05 \%$} & B & 0.776 & 0.166 & 0.975 & 0.787 & 0.050 & 0.519 \\
\hline & $\mathbf{A B}$ & 1.34 & 0.288 & 1.68 & 1.36 & 0.087 & 0.899 \\
\hline \multicolumn{8}{|c|}{ Season 2014-2015 } \\
\hline & Without & 17.09 & 2.72 & 27.36 & 12.73 & 1.82 & 11.79 \\
\hline & SA1 & 18.96 & 3.10 & 30.52 & 14.88 & 2.17 & 14.04 \\
\hline \multirow[t]{3}{*}{ S1 } & SA2 & 21.14 & 3.71 & 32.92 & 16.96 & 2.56 & 15.70 \\
\hline & AA1 & 22.91 & 4.19 & 35.61 & 18.76 & 2.88 & 17.29 \\
\hline & AA2 & 29.07 & 5.05 & 43.14 & 20.19 & 3.47 & 21.83 \\
\hline \multirow[t]{3}{*}{ Mean } & & 21.83 & 3.75 & 33.91 & 16.70 & 2.58 & 16.13 \\
\hline & Without & 8.74 & 0.79 & 12.33 & 7.09 & 0.82 & 7.24 \\
\hline & SA1 & 11.81 & 1.14 & 16.10 & 7.92 & 1.02 & 7.84 \\
\hline \multirow[t]{3}{*}{ S2 } & SA2 & 13.59 & 1.49 & 18.14 & 9.00 & 1.20 & 8.62 \\
\hline & AA1 & 13.93 & 1.77 & 18.68 & 9.94 & 1.42 & 9.44 \\
\hline & AA2 & 16.12 & 2.57 & 24.61 & 10.58 & 1.72 & 11.55 \\
\hline \multirow[t]{3}{*}{ Mean } & & 12.84 & 1.55 & 17.96 & 8.90 & 1.24 & 8.94 \\
\hline & Without & 0.00 & 0.00 & 0.00 & 0.00 & 0.00 & 0.00 \\
\hline & SA1 & 5.04 & 0.35 & 7.57 & 3.92 & 0.28 & 3.74 \\
\hline \multirow[t]{3}{*}{ S3 } & SA2 & 5.94 & 0.47 & 9.17 & 5.13 & 0.42 & 5.02 \\
\hline & AA1 & 6.96 & 0.59 & 10.91 & 6.15 & 0.56 & 6.15 \\
\hline & AA2 & 8.12 & 0.73 & 12.20 & 6.88 & 0.71 & 7.02 \\
\hline \multicolumn{2}{|l|}{ Mean } & 5.21 & 0.43 & 8.00 & 4.42 & 0.39 & 4.39 \\
\hline \multicolumn{8}{|c|}{ Mean of treatment (foliar spray) } \\
\hline \multicolumn{2}{|l|}{ Without } & 8.61 & 1.17 & 13.21 & 6.61 & 0.88 & 6.34 \\
\hline \multicolumn{2}{|l|}{ SA1 } & 11.94 & 1.53 & 18.06 & 8.91 & 1.16 & 8.54 \\
\hline \multicolumn{2}{|l|}{ SA2 } & 13.56 & 1.89 & 20.07 & 10.36 & 1.39 & 9.78 \\
\hline \multicolumn{2}{|l|}{ AA1 } & 14.60 & 2.19 & 21.73 & 11.62 & 1.62 & 10.96 \\
\hline \multirow[t]{2}{*}{ AA2 } & & 17.77 & 2.78 & 26.70 & 12.55 & 1.97 & 13.47 \\
\hline & $\mathbf{A}$ & 0.438 & 0.121 & 0.615 & 2.196 & 0.038 & 2.491 \\
\hline \multirow[t]{2}{*}{ LSD $0.05 \%$} & B & 0.566 & 0.156 & 0.794 & 2.835 & 0.049 & 3.216 \\
\hline & $\mathbf{A B}$ & 0.980 & 0.270 & 1.375 & 4.910 & 0.085 & 5.571 \\
\hline
\end{tabular}

Note. SA $1=0.1 \%$ Salicylic acid; SA2 $=0.2 \%$ Salicylic acid; AA1 $=0.1 \%$ Ascorbic acid; AA2 $=0.2 \%$ Ascorbic acid; $\mathrm{S} 1=3 \mathrm{dSm}^{-1} ; \mathrm{S} 2=6 \mathrm{dSm}^{-1} ; \mathrm{S} 3=9 \mathrm{dSm}^{-1}$; NS: Not significant at $\mathrm{t} 0.05$.

Data show that, straw and grain N, P and K uptake by wheat was decreased with increasing the soil salinity level. This trend was found to be true under all foliar sprays with salicylic and ascorbic acids at different rates. As mentioned before the untreated plants (without foliar spray) at maturity stage died off due to extremely high salinity $\left(10.65 \mathrm{dSm}^{-1}\right)$ in the two seasons. Observed results are similar to those reported by Ahmad (2007) and Elgharbly (2008) who stated that the N, P and K content of wheat plants were significantly decreased with increasing soil salinity stress in sandy loam soils. Salts might inhibit plant growth and nutrient uptake by increasing the osmotic stress, nutritional imbalance, and specific ion toxicity. The extent of damage depends on 
the severity of stress, growth conditions and plant sensitivity to salinity. Also Salt stress markedly decreased the plant fresh, dry biomasses and nutrient uptake of $\mathrm{Na}^{+}$, and $\mathrm{Cl}^{-}$concentrations (Naheed et al., 2008). With respect to the effect of foliar sprays with salicylic and ascorbic acids at different rates, data reveal that straw and grain $\mathrm{N}$, $\mathrm{P}$ and K-uptake was increased with increasing the application rate of foliar spray with both acids under the soil salinity level in the two seasons. The highest values occurred with AA2 treatment followed by AA1, SA2, SA1 and untreated plants that was in descending order of the two seasons. The increased values of grains $\mathrm{N}, \mathrm{P}$ and $\mathrm{K}$ uptake by the AA2 treatment over the other treatments was represented by $(62.5,66$ and $62.5 \%$, respectively) under S1 level "3.21 dSm" $53 \%$, respectively) under S3 level " $10.65 \mathrm{dSm}^{-1}$ " in the first season. The same trend was found in the second season. Similarly, Salicylic acid enhanced the growth of wheat plants under water stress (Singh \& Usha, 2003) maize (Khodary, 2004) and barley (El-Tayed, 2005). From statistical analysis, results showed that the foliar spray with ascorbic acid at different rates under the saline level gave a significant increase in straw and grains NPK-uptake compared to foliar spray with salicylic acid in the two seasons. This result confirmed by Janda et al. (2007). Ascorbic acid regulates plant growth owing to its effects on cell division and differentiation.

\subsection{Anatomical Responses}

Data presented in (Table 6) and (Figure 1) showed that wheat plant subjected to salinity stress decreased thickness of leaf blade due to a corresponding decrease in thickness of mesophell tissue by increasing soli salinity. In addition, length and width of midvein were decreased due to decreasing length and width of vascular bundle for midvein. Moreover, thickness of scalaranchyma tissue and diameter of xylem vessels/bundle were also decreased, the low salinity treatment $\left(3.21 \mathrm{dSm}^{-1}\right)$ reduced these parameters to a lesser degree than the moderate salinity $\left(6.32 \mathrm{dSm}^{-1}\right)$ and high salinity $\left(10.65 \mathrm{dSm}^{-1}\right)$. These results are in harmony with the findings of Khodos et al. (1976) and Abou-Bakr et al. (1998) on wheat plants.

Table 6. Measurement in micron of certain light microscopically features of transverse section through the leaf blade from the apex of wheat plant (fully expanded leaf) as affected by the foliar application with (AA \& SA) and different levels of salinity stress during 2013/2014

\begin{tabular}{|c|c|c|c|c|c|c|c|c|c|}
\hline \multicolumn{2}{|c|}{ Characters Treatments } & \multirow[b]{2}{*}{$\begin{array}{l}\text { Thickness } \\
\text { of blade }\end{array}$} & \multirow{2}{*}{$\begin{array}{l}\text { Thickness of } \\
\text { mesophyll } \\
\text { tissue }\end{array}$} & \multirow[b]{2}{*}{$\begin{array}{l}\text { Length of } \\
\text { midvein }\end{array}$} & \multirow[b]{2}{*}{$\begin{array}{l}\text { Width of } \\
\text { midvein }\end{array}$} & \multirow{2}{*}{$\begin{array}{l}\text { Length of } \\
\text { vascular } \\
\text { boundles } \\
\text { midvein }\end{array}$} & \multirow{2}{*}{$\begin{array}{l}\text { Width of } \\
\text { vascular } \\
\text { boundles } \\
\text { midvein }\end{array}$} & \multirow{2}{*}{$\begin{array}{l}\text { Thickness of } \\
\text { Schalaranchyma } \\
\text { tissue }\end{array}$} & \multirow{2}{*}{$\begin{array}{l}\text { Diameter } \\
\text { of xylem } \\
\text { vessel }\end{array}$} \\
\hline $\begin{array}{l}\text { Levels of } \\
\text { salinity }\end{array}$ & $\begin{array}{l}\text { Foliar spray } \\
\text { of anti-oxidants }\end{array}$ & & & & & & & & \\
\hline$\overline{S 1}$ & control & 213.6 & 179.4 & 650.3 & 777.8 & 134.2 & 140.6 & 103.6 & 35.7 \\
\hline $3.21 \mathrm{dSm}^{-1}$ & AA $0.2 \%$ & 232.8 & 184.5 & 682.5 & 905.8 & 142.5 & 145.2 & 107.4 & 36.8 \\
\hline $\mathbf{S} 2$ & control & 184.7 & 150.6 & 394.7 & 586.4 & 126.5 & 121.5 & 74.6 & 28.8 \\
\hline $6.32 \mathrm{dSm}^{-1}$ & AA $0.2 \%$ & 221.2 & 174.8 & 510.6 & 745.7 & 131.6 & 128.6 & 80.8 & 31.4 \\
\hline S 3 & control & 152.9 & 129.8 & 245.5 & 514.6 & 92.6 & 101.4 & 36.5 & 23.4 \\
\hline $10.65 \mathrm{dSm}^{-1}$ & AA $0.2 \%$ & 179.6 & 158.3 & 320.6 & 583.2 & 108.4 & 119.5 & 48.6 & 28.6 \\
\hline
\end{tabular}

Therefore, it could be concluded that salinity stress may have an inhibitor effect on the activity of the various initial cells forming the leaf blade with regard to cell division and enlargement. Generally, the high level of salinity stress caused a reduction in the conductive tissues of wheat plant. The decrease in mesophyll tissue, xylem and phloem leads to a slow rate in the translocation of photoassimlates towards the developing grains. Furthermore, the decreases in the diameter of vascular bundle in the leaf blade resulted in lowering the accumulation of necessary water required for photosynthesis according to Khafagy et al. (2009) on sweet pepper plant. As for the effect of antioxidant treatment AA at the rate of $0.2 \%$ showed an increased in most investigated anatomical characters (thickness of leaf blade, thickness of mesophell tissue, length and width of midvein, length and width of vascular bundle for midvein, length and thickness of scalaranchyma tissue and diameter of xylem vessels/bundle) as compared to the control. These results are in accordance to those obtained Gadalla (2009) on wheat plants and Khafagy et al. (2009) on sweet pepper plant. The favourable effect of AA on anatomical leaves might be due to its effect on xylem vessel differentiation and development, growth rate, stimulating cell expansion, vacuolation and fluid uptake and cell division (Conklin, 2002). 

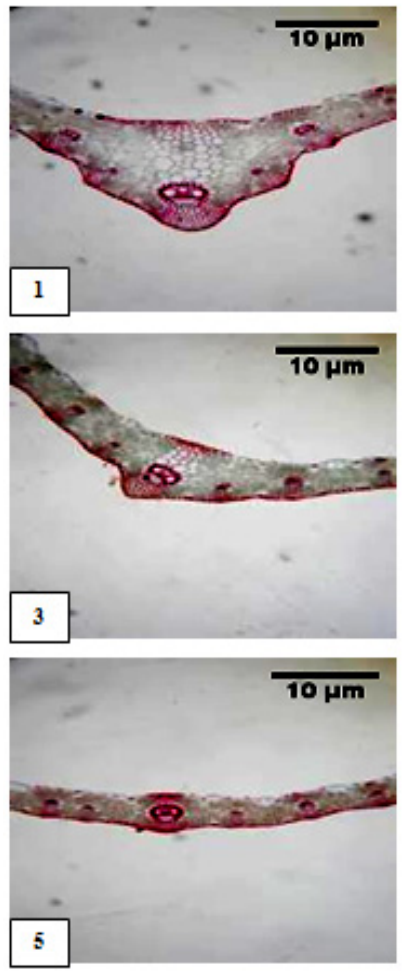
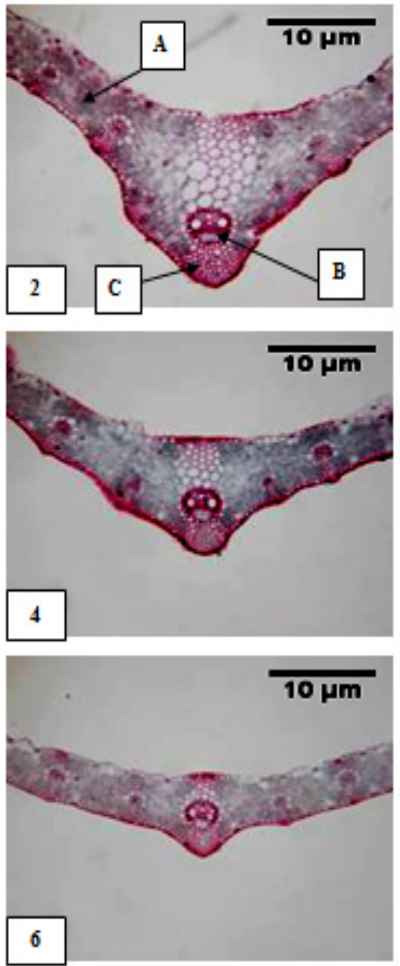

Figure 1. Transverse sections in the flag leaf blade of wheat main stem as affected by the interaction treatments between foliar application with antioxidant (AA $0.2 \%$ ) and three levels of salinity stress during the second growing season (2014/2015). Scale bars $10 \mu \mathrm{m}$

Note. (1) $3.21 \mathrm{dSm}^{-1}$ (S1) spraying with distilled water; (2) $3.21 \mathrm{dSm}^{-1}$ (S1) spraying with AA $0.2 \%$; (3) 6.32 $\mathrm{dSm}^{-1}$ (S2) spraying with with distilled water; (4) $6.32 \mathrm{dSm}^{-1}$ (S2) spraying with AA $0.2 \%$; (5) $10.65 \mathrm{dSm}^{-1}$ (S3) spraying with distilled water; (6) $10.65 \mathrm{dSm}^{-1}$ (S3) spraying with AA $0.2 \%$, A: Mesophyll tissue, B: Midrib vasccular bundle, C: Schalaranchyma tissue.

\section{References}

Abd El-Aziz, Nahed, G., Azza, M. M., \& El-Habba, E. (2006). Effect of foliar spraying with ascorbic acid on growth and chemical constituents of Khaya senegalensis grown under salt condition. American-Eurasian J. Agric. \& Environ. Sci., 1(3), 207-214.

Abou-Bakr, Z. Y. M., Hegazi, A. E. M., Naim, M. A., \& Khalfallah, A. A. M. (1998). The role played by water stress and antitranspirant on water relations, stomatal regulation and anatomical character of wheat. Desert Institute Bulletin Egypt, 48(2), 227-257.

Ackerson, R.C. (1984). Carbn partitioning and translocation in relation to osmotic adjustment. Agron. Abstract, $67^{\text {th }}$ Ann. Meet. Las Vegas, NV, 25-30.

Ahmad, S. A. A. (2007). Response of Plant to Phosphorus Fertilization under Different Levels of Salinity Stress. M.Sc. Thesis Fac. Agric. Benha Univ.

Bates, L. S., Waldern, R. P., \& Teare, I. D. (1973). Rapid determination of free proline for water stress studies. Plant Soil, 39, 205-208. http://dx.doi.org/10.1007/BF00018060

Batool, E. J., Zahoor Ahmad, S. A. J., \& Faheem, A. F. T. (2012). Effect of exogenous application of ascorbic acid on antioxidantenzyme activities, proline contents, and growth parameters ofSaccharum spp. hybrid cv. HSF-240 under salt stress. Turk J Biol., 36, 630-640.

Beltagi, M. S. (2008). Exogenous ascorbic acid (Vitamin C) induced anabolic changes for salt tolerance in chick pea (Cicer arietinum L.) plants. Afr J Plant Sci, 2, 118-123.

Bishni, U. R., \& Hughes, I. L. (1979). Agronomic performance and protein content of fall - planted tritica, wheat and rye. Agron. J., 71, 359-360. http://dx.doi.org/10.2134/agronj1979.00021962007100020032x 
Black, C. A. (1968). Soil plant relationships (2nd ed.). John Wiley and Sons, NY, USA.

Blokhina, O., Eija Virolainen, E., \& Fagerstedt, K. V. (2002). Antioxidants, Oxidative Damage and Oxygen Deprivation Stress: A Review. Annals of Botany, 91, 179-194. http://dx.doi.org/10.1093/aob/mcf1 18

Bray, E. A. (1993). Molecular responses to water deficit. Plant Physiol., 103, 1035-140.

Chapman, D. H., \& Pratt, P. F. (1961). Methods of analysis for soil, plant and waters. California. Univ.; Division of Agric. Sci.

Conklin, P. I. (2002). Recent advances in the role and biosynthesis of ascorbic acid in plants. Plant Cell Environ, 24, 383-94. http://dx.doi.org/10.1046/j.1365-3040.2001.00686.x

Conklin, P. L. (2001). Recent advances in the role and biosynthesis of ascorbic acid in plants. Plant Cell Environ, 24, 383-394. http://dx.doi.org/10.1046/j.1365-3040.2001.00686.x

Conklin, P. L., \& Barth, C. (2004). Ascorbic acid, a familiar small molecule intertwined in the response of plants to ozone, pathogens and the onset of senescence. Plant Cell Environ., 27, 959-970. http://dx.doi.org/10.1111/j.1365-3040.2004.01203.x

Debolt, S., Melino, V., \& Ford, C. M. (2007). Ascorbate as a biosynthetic precursor in plants. Ann Bot, 99, 3-8. http://dx.doi.org/10.1093/aob/mcl236

El Tayed, M. A. (2005). Response of barley grains to the interactive effect of salinity and salicylic acid. Plant Growth Regul., 45, 215-224. http://dx.doi.org/10.1007/s10725-005-4928-1

Elgharably, A. G. (2008). Nutrient Availability and Wheat Growth as Affected by Plant Residues and Inorganic Fertilizers in Saline Soils. Ph.D. Thesis Soil and Land systems, Earth Environ. Sci., Univ. Adelide, Aust.

Gadalla, S. F. (2009). The role of antioxidants in inducing wheat flag leaf osmotic adjustment under salinity stress. J. Agric. Sci. Mansoura Univ., 34(11), 10663-10685.

Grace, S. C., \& Logan, B. A. (2000). Energy dissipation and radical scavenging by the plant phenylpropanoid pathway. Royal Society. Biological Sciences, 355, 1499-1510. http://dx.doi.org/10.1098/rstb.2000.0710

Grattan, S. R., \& Grieve, C. M. (1999). Salinity-Mineral nutrient relations in horticultural crops. Sci. Hort., 78, 127-157. http://dx.doi.org/10.1016/S0304-4238(98)00192-7

Gunes, A., Inal, A., Eraslan, F., Bacci, E. G., \& Cicek, N. (2007). Salicylic acid induced changes of some physiological parameters sympomatic for oxclative stress and mineral nutrition in maize (Zea mays L.) grown under salinity. J. Plant Physiol., 164(4), 726-732.

Gutfinger, T. (1981). Polyphenols in olive oils. J. Am. Oil Chem. Soc., 58, 966-986. http://dx.doi.org/10.1007/BF 02659771

Hussain, S., \& Ismail, S. (1994). Effect of salt and water stress on growth and biomass production in Helianthus annuus L. Pakistan Journal of Botany, 26, 127-138.

Hussein, M. M., Balbaa, L. K., \& Gaballah, M. S. (2007). Salicylic Acid and Salinity Effects on Growth of Maize Plants. R. J. of Agric. and Biol. Sci., 3(4), 321-328.

Jackson, M. L. (1973). Soil Chemical Analysis. Prentice Hall, Ic., Englewood Califfs, New Jersy.

Janda, T., Horvath, E., Szalai, C., \& Paldi, E. (2007). Role of salicylic acid in the induction of abiotic stress tolerance. In S. Hayat \& A. Ahmed (Eds.), Salicylic acid: A plant hormone (pp. 91-154). Springer, Dordrecht, The Netherlands. http://dx.doi.org/10.1007/1-4020-5184-0_5

Khafagy, M. A., Arafa, A. A., \& El-Banna, M. F. (2009). Glycinebetaine and ascorbic acid can alleviate the harmful effects of $\mathrm{NaCl}$ salinity in sweet pepper. Australian Journal of Crop Science, 3(5), 257-267.

Khodary, S. F. A. (2004). Effect of salicylic acid on growth ,photosynthesis and carbohydrate metabolism in salt-stressed maize plants. Int. J. Agric. Biol., 6, 5-8.

Khodos, V. M., Shmat'ko, I. G., \& Vaida, P. V. (1976). Synthesis of sugars and formation of cell walls and elements of the vascular system of wheat leaves under different regimes of water supply. Dopovidi Akademii Nauk Ukrains'koi RSR, B(2), 172-175.

Liso, R., De Gara, L., Tommasi, F., \& Arrigoni, O. (1985). Ascorbic acid requirement for increased peroxidase activity during potato tuber slice aging. FEBS Lett., 187, 141-45. http://dx.doi.org/10.1016/0014-5793(85)81230-8

Merwad, A. M. A., \& Abdel-Fattah, M. K. (2015). Effect of some soil amendments and foliar spray of salicylic 
and ascorbic acids on sorghum under saline calcareous soil conditions. Internal. J. Soil Sci., 10(1), 28-36. http://dx.doi.org/10.3923/ijss.2015.28.36

Mohamed, A. A., \& Aly, A. A. (2008). Alternations of some secondary metabolites and enzymes activity by using exogenous antioxidant compound in onion plants grown under seawater salt stress. American-Eurasian Journal of Scientific Research, 3, 139-146.

Murtaza, G., Ghafar, A., \& Gadir, M. (2006). Irrigation and soil management strategies for using saline and sodic water in cotton-wheat rotation. Agric. Water Management, 81(1-2), 98-114. http://dx.doi.org/10.1016/j.agw at.2005.03.003

Naheed, G., Shahbaz, M., \& Akram, A. (2008). Interactive effect of rooting medium application of phosphorus and $\mathrm{NaCl}$ on plant biomass and mineral nutrients of rice (Oryza sativa L.) Pak.J. Bot., 40, 1601-1608.

Nassar, M. A., \& El-Sahhar, K. F. (1998). Botanical Preparations and Microscopy (Microtechnique) (p. 219). Academic Bookshop, Dokki, Giza, Egypt.

Noctor, G., \& Foyer, C. H. (1998). Ascorbate and glutathione: keeping active oxygen under control. Annual Review of Plant Physiology and Plant Molecular Biology, 49, 249-279. http://dx.doi.org/10.1146/annurev.a rplant.49.1.249

Ozdemir, O., Melike, B., Tijen, D., \& Ismail, T. (2004). Effects of 24-epibrassinolide on seed germination, seedling growth, lipid peroxidation, proline content and antioxidative system of rice (Oryza sativa L.) under salinity stress. Plant Growth Regulation, 42, 203-211. http://dx.doi.org/10.1023/B:GROW.0000026509.259 95.13

Perez-Alfocea, F., Balibrea, M. E., Santa Cruz, A., \& Estan, M. T. (1996). Agronomical and physiological characterization of salinity tolerance in a commercial tomato hybrid. Plant Soil, 180, 251-257. http://dx.doi.org/10.1007/BF00015308

Piper, C. S. (1950). Soil and Plant Anaylsis. Interscince Publishers Inc. New York.

Rajarm, S., \& Braun, H. S. (2006). Wheat yield potential. Farm policy J., 3(1), 103-107.

Roy, D., Basu, N., Marilk, R., \& Banerjee, S. K. (1995). Changes in levels of endogenous gibberellins and Abscicic acid in salt sensitive germination rice by $\mathrm{NaCl}$ salinity. Plant Physiol. and Biochem., 22(2), 200-202.

Rus, A. M., Rios, S., Olmos, E., Santa-Cruz, A., \& Bolarin, M. C. (2000). Longterm culture modifies the salt responses of callus lines of salt-tolerant and salt-sensitive tomato species. J Plant Physiol., 157, 413-420. http://dx.doi.org/10.1016/S0176-1617(00)80026-7

Sadat Noori, S. A., \& McNeilly, T. (2000). Assessment of variability in salt tolerance based on seedling growth in Triticum durum Desf. Genetic Resour. Crop Evol., 47, $285-291$. http://dx.doi.org/10.1023/A:1008749312148

Salama, K. H. A. (2009). Amelioration of NaCl-induced alterations on the plasma membrane of Allium cepa L. by ascorbic acid. Aust J Basic Appl Sci, 3, 990-994.

Shakirova, M. F., Sakhabutdinova, A. R., Bezrukova, M. V., Fatkhutdinova, R. A., \& Fatkhutdinova, D. R. (2003). Changes in the hormonal status of wheat seedlings induced by salicylic acid and salinity. Plant Science, 164(3), 317-322. http://dx.doi.org/10.1016/S0168-9452(02)00415-6

Singh, B., \& Usha, K. (2003). Salicylic acid induced physiological and biochemical changes in wheat seedlings under water stress. Plant Growth Regul., 39, 137-141. http://dx.doi.org/10.1023/A:1022556103536

Smirnoff, N. (1996). The function and metabolism of ascorbic acid in plant. Ann. Bot.., 78:661-669. http://dx.doi.org/10.1006/anbo.1996.0175

Snedecor, G. W., \& Cochran, W. G. (1990). Statistical methods (8th ed.). Iowa State Univ. Press, Ames Iowa, USA.

Snell, F. D., \& Snell, C. T. (1954). Colorimetric methods of analysis (3rd ed., pp. 512-513; pp. 516-518). Van Nostrand Company. New York.

Takahama, U., \& Oniki, T. (1994). Effects of ascorbate on the oxidation of derivatives of hydroxycinnamic acid and the mechanism of oxidation of sinapic acid by cell wall-bound peroxidases. Plant Cell Physiol., 35, 593-600. 
Watanabe, F. S., \& Olsen, S. R. (1965). Test of ascorbic acid method for determing phosphorus in water and NaHCO3 extracts from soil. Soil Sci. Soc. Am. Proc., 29, 677-678. http://dx.doi.org/10.2136/sssaj1965.036 $15995002900060025 x$

Zahra, S. M., khajeh, H., Bahabadi1, S. E., \& Sabbagh, S. K. (2012). Changes on proline, phenolic compounds and activity of antioxidant enzymes in Anethum graveolens L. under salt stress. International $J$. of Agronomy and Plant Production, 3(S), 710-715.

\section{Copyrights}

Copyright for this article is retained by the author(s), with first publication rights granted to the journal.

This is an open-access article distributed under the terms and conditions of the Creative Commons Attribution license (http://creativecommons.org/licenses/by/3.0/). 